\title{
Different Perception of Health Status and Importance of Physical Activity among Croatian, Slovak and Czech Youth
}

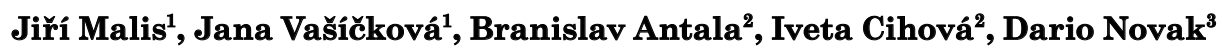 \\ ${ }^{1}$ Palacky University Olomouc, Faculty of Physical Culture, Olomouc, Czech Republic \\ ${ }^{2}$ Comenius University in Bratislava, Faculty of Physical Education and Sport, Bratislava, Slovakia \\ ${ }^{3}$ University of Zagreb, Faculty of Kinesiology, Zagreb, Croatia
}

\begin{abstract}
A B S T R A C T
The main aim of the study was to compare self-perception of health status and importance of physical activity in students in Croatia, Slovakia and the Czech Republic. We used a self-designed questionnaire originally prepared in the Slovak language that was translated in mother languages for Czech and Croatian students. The questionnaire consists of five parts (we focused only on one part-physical activity and health) and basic demographical data. We obtained 1,368 questionnaires from first and last grade of high school students. For answers to 15 statements, students used 5-point Likert scale. Health status was perceived as excellent or very good by large portion of Croatian boys compared to Czech and Slovak boys. Physical activity helps students to be fit and to better assess situation in real life. Importance of physical activity should be promoted because not only does it make people fit but also helps them work, study, and relax better.
\end{abstract}

Key words: self-perceived health status, physical activity, schoolwork, high school student, questionnaire

\section{Introduction}

Perception of health status of children and adolescents differs from adult's perception because it is important for youngsters how a person feels. Therefore, we compare the self-perception health status with importance of physical activity among students in Croatia, Slovakia and the Czech Republic. There are also other more important indicators apart from somatic ones, for example, how a person gets along with other people or schoolmates, and copes with demands of everyday life ${ }^{1}$. As mentioned in this study, the term subjective health denotes a multidimensional construct covering physical, emotional, mental, social and behavioural component of well-being ${ }^{1}$.

Self-rated health, self-rated physical activity and self-rated fitness are independent predictors of mortality ${ }^{2}$. Several correlates were found to determine self-reported health status in adult population such as psychological well-being, personality, lifestyle, and social context ${ }^{3,4}$. From the literature search we can find very synonymous terms as self-rated health ${ }^{5-8}$, self-reported health status ${ }^{8}$, self-rated perception of health ${ }^{2}$, self-assessment of health status $^{9,10}$ and others that can be measured from various points of view with many instruments developed for vari- ous purposes. These terms can be used for the same content specific meaning, but it is crucial how the health status is obtained. It can be a very simple question or a mix of several targeted questions describing different health problems and diseases.

Regarding the questionnaires, Scientific Advisory Committee (SAC) of the Medical Outcome Trust dealt with attributes and review criteria for assessing health status and quality-of-life instruments and eight of them warrant consideration in evaluation ${ }^{11}$. These criteria can be used when the scientists investigate complexity of certain questionnaires ${ }^{12}$. However, in the school system, we wanted to know personal feelings about health status rather than some complicated and hardly analysed information.

Positive relationship between physical activity (leisure time PA) status and self-reported health across population subgroups within Europe was determined ${ }^{5}$. Positive well-being during adolescence was significantly associated with reporting better perceived general health during young adulthood and with fewer risky health behaviours ${ }^{13}$. On the other hand, smoking status and the 
perception of body image as overweight were the most frequent and consistent predictors of poor health among adolescents in Colorado, $\mathrm{USA}^{10}$.

Importance of adequate sleep (no shorter than $6 \mathrm{~h}$ and no longer than 9h) in physical and mental health was studied in older Australian adults ${ }^{6}$. Sleeping problems accompanied by negative psychosocial factors deteriorate also well-being in British seniors ${ }^{14}$.

According to Special Eurobarometer study in 2005, $20.7 \%$ of adults 15 years of age and older reported very good self-rated health, $49.7 \%$ good health, $21.5 \%$ neither good or bad, $6.6 \%$ bad and $1.1 \%$ very bad health ${ }^{15}$. In this study, there were mentioned some determinants of good self-rated health in men (a lot of occupational PA, doing $\mathrm{PA}$ at home, and some leisure PA) and one determinant of self-rated health in women (doing little, some, or a lot of leisure time PA).

The main aim of the study was to compare students' opinions about their perceived health status and importance of physical activity within their lifestyle. We tested the hypothesis that perceived health status varies among students from three different countries and that importance of PA is perceived slightly different in the young generations.

\section{Material and Methods}

Team of authors invented the questionnaire that was distributed among upper secondary students in three countries - Czech Republic, Slovakia, and Croatia. The questionnaire was originally in the Slovakian language and translated into the Czech and Croatian languages. The questionnaire consists of five parts and demographical data. The parts focused on Physical Education lessons, social capital, information and communication technology, physical activity and health, and inclusive education. In this study we focused only on how students perceived their PE lessons and how they perceived their physical activity and health. During designing this part of our questionnaire we used the „Questionnaire on Phys- ical Activity" that Mok et al. ${ }^{16}$ created for the project "OnLine-Streaming Brain Breaks". We obtained 1,409 questionnaires and 41 of them had to be eliminated (2.9\%) due to incomplete information or age limit (15-19-yearold). The final sample consisted of 1,368 questionnaires. We asked students from the first grade and from the last grade (10 schools in three countries) to complete the questionnaire at the end of school year 2017/18.

For obtaining information that we wanted to analyse we chose a question asking about perception of their health status: "How do you evaluate your health?" with possible answers: excellent - very good - good - bad very bad.

Importance of physical activity within students' lifestyle was assessed based on 15 statements where students could choose from these answers: fully agree - partially agree - sometimes agree/disagree - partially disagree - fully disagree.

For descriptive purposes we merged fully agree and partially agree into one category "agree" and the same for fully disagree and partially disagree - category "disagree". But statistical analysis was carried out for all five categories among three countries.

\section{Statistics}

We used basic statistical descriptions and after testing for normal distribution we decided to use nonparametric tests for two or more independent samples (Kruskal-Wallis test) as our variables were not normally distributed (Kolmogorov-Smirnov test - range 0.18-0.33; $\mathrm{p}<0.01)$. For evaluation of the differences we used coefficient effect size $\eta^{2}{ }^{17}$ with defined effects $\left[\eta^{2} \geq 0.14\right.$ great effect; $\left.\eta^{2} \in<0.06-0.14\right)$ medium effect; $\eta^{2} \in<0.01-0.06$ ) small effect]. Detailed percentages are described in Table 1 below.

The data we analysed was not normally distributed, so we used nonparametric statistical test to find out differences between countries and between genders.

TABLE 1

DEMOGRAPHIC CHARACTERISTICS OF PARTICIPANTS

\begin{tabular}{llccc}
\hline \multirow{2}{*}{ Country } & Gender & Age & Body height & Body weight \\
\cline { 3 - 4 } & & $\mathrm{M} \pm \mathrm{SD}$ & $\mathrm{M} \pm \mathrm{SD}$ & $\mathrm{M} \pm \mathrm{SD}$ \\
\hline Slovakia (n=522) & Girls (n=273) & $16.23 \pm 1.34$ & $168.27 \pm 6.13$ & $56.50 \pm 7.05$ \\
& Boys (n=249) & $16.64 \pm 1.31$ & $181.30 \pm 7.23$ & $70.78 \pm 11.33$ \\
Czech Republic (n=470) & Girls (n=281) & $16.88 \pm 1.11$ & $167.90 \pm 6.60$ & $58.08 \pm 7.75$ \\
& Boys (n=189) & $16.94 \pm 1.10$ & $180.44 \pm 7.56$ & $71.43 \pm 10.78$ \\
Croatia (n=376) & Girls (n=234) & $17.44 \pm 0.79$ & $167.67 \pm 6.15$ & $58.73 \pm 8.58$ \\
& Boys (n=142) & $17.47 \pm 0.81$ & $181.81 \pm 7.57$ & $73.97 \pm 11.55$ \\
\hline
\end{tabular}

Data we analysed were not normally distributed, so we used nonparametric statistical test to find differences between countries and between genders. 


\section{Results}

We compared perceived health status of students from three countries and found out that many Croatian students perceived their health as excellent or very good $(29.5 \%$; $38.3 \%$ resp.) and there exists significant difference between Croatian students and students from other two countries $\left(\mathrm{x}^{2}=24.21 ; \mathrm{p}<0.01 ; \mathrm{r}=0.13\right)$. Czech and Slovak boys, and Croatian girls were more critical about their perceived health status $(7.4 \% ; 6.4 \% ; 6.4 \%$ resp.) and reported bad or very bad health status. Detailed percentages are described in Figure 1 below.

Regarding students' evaluation of 15 statements about importance of physical activity and exercising we found small effects in seven of them (Table 2). "Being active helps me to be fit" is important for $90 \%$ of Slovak students but only for $69.4 \%$ of Croatian students. More Croatian students think that PA helps them better assess situation compared

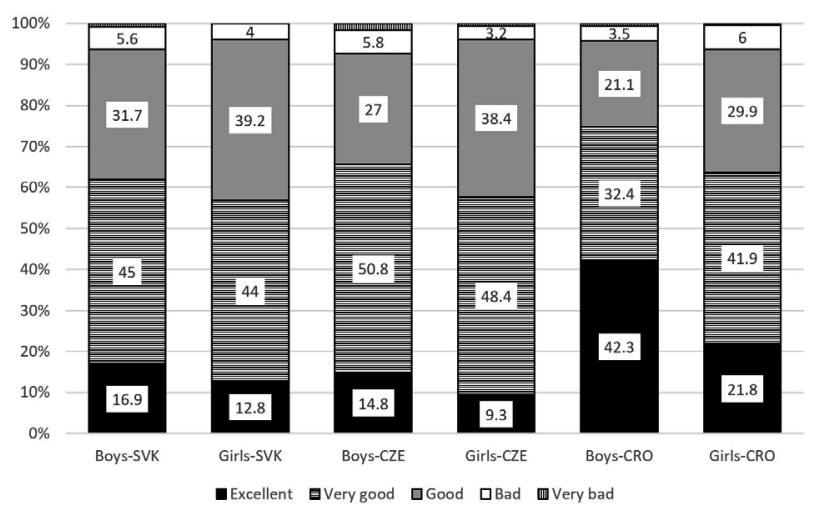

Fig.1. Perceived health status in Slovak, Czech, and Croatian students (gender aspect). to Czech students (56.1\% versus $36.4 \%$ ). Connection between being active and health is perceived and agreed by Slovak students (92\%) while $7.2 \%$ of Croatian students do not agree. Physical activity is also useful for better work at school which is true for $50.3 \%$ Croatian students but only for $28.8 \%$ of Czech students. Detailed percentages are described in Table 2 below.

We also analysed gender differences in particular countries and found statistically significant differences in 4 statements. We found that more Croatian boys than girls agreed that "Being active helps me to be fit" (Question 1). More differences we obtained in Czech students (question 4, 6 , and 9). More Czech boys than girls agreed that "Being active helps me to better assess situations" and that "Being active allows me to gain new experiences". On the other hand, more Czech girls than boys agreed that "Being active helps me sleep better". Detailed percentages are described in Figure 2 below.

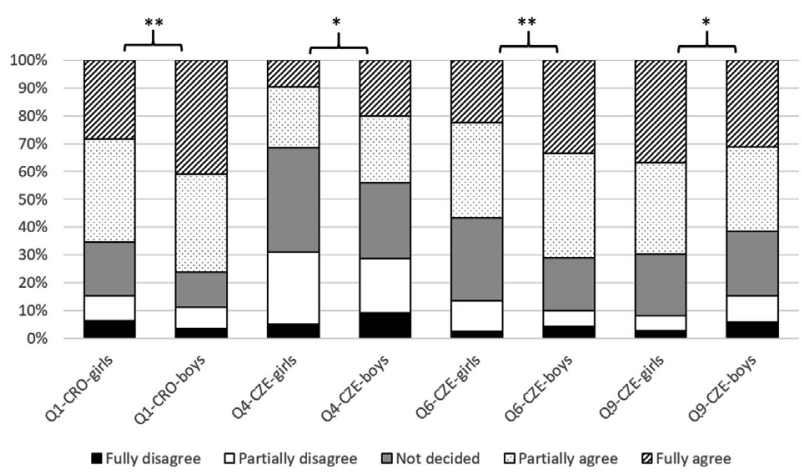

Fig. 2. Selected questions about perception of physical activity divided according to country and gender (percentage) with indication of statistical differences.

TABLE 2

STATEMENT ABOUT IMPORTANCE OF PHYSICAL ACTIVITY

\begin{tabular}{|c|c|c|c|c|c|c|c|c|c|}
\hline \multirow{2}{*}{$\begin{array}{l}\text { Country } \\
\text { Statements (agreement in \%) }\end{array}$} & \multicolumn{2}{|c|}{$\begin{array}{c}\text { Czech R. } \\
(\mathrm{n}=470)\end{array}$} & \multicolumn{2}{|c|}{$\begin{array}{c}\text { Slovakia } \\
(\mathrm{n}=522)\end{array}$} & \multicolumn{2}{|c|}{ Croatia $(n=376)$} & \multirow[t]{2}{*}{$x^{2}$} & \multirow[t]{2}{*}{$\mathrm{p}$} & \multirow[t]{2}{*}{$\eta^{2}$} \\
\hline & Agree & Disagree & Agree & Disagree & Agree & Disagree & & & \\
\hline 1. Being active helps me to be fit. & 88.9 & 3.5 & 90.00 & 3.6 & 69.4 & 13.8 & $102.37 * *$ & $<0.01$ & 0.04 \\
\hline 2. Being active helps me relax. & 65.7 & 12.2 & 70.00 & 11.5 & 66.0 & 13.6 & 2.92 & 0.23 & \\
\hline 3. Being active helps me think better. & 61.0 & 15.5 & 67.8 & 10.2 & 64.9 & 13.5 & $10.42^{* *}$ & 0.01 & \\
\hline 4. Being active helps to me to better assess situations. & 36.4 & 30.0 & 47.9 & 17.6 & 56.1 & 12.2 & $47.83^{* *}$ & $<0.01$ & 0.02 \\
\hline 5. Being active helps me to improve my perception of myself. & 59.3 & 19.2 & 61.7 & 13.4 & 55.2 & 14.6 & 1.33 & 0.52 & \\
\hline 6. Being active allows me to gain new experiences. & 62.3 & 12.1 & 69.0 & 9.4 & 62.2 & 14.9 & $5.85^{*}$ & 0.05 & \\
\hline 7. Being active helps me increase my firm willpower. & 72.6 & 10.6 & 71.1 & 9.0 & 70.7 & 11.7 & 2.81 & 0.25 & \\
\hline 8. Being active helps me improve my health. & 89.6 & 2.4 & 92.0 & 2.8 & 82.1 & 7.2 & $38.22 * *$ & $<0.01$ & 0.01 \\
\hline 9. Being active helps me sleep better. & 66.4 & 11.0 & 72.8 & 9.4 & 65.7 & 11.7 & $10.75^{* *}$ & 0.01 & \\
\hline 10. Being active helps me work better in school. & 28.8 & 31.0 & 41.0 & 25.3 & 50.3 & 20.7 & $35.31^{* *}$ & $<0.01$ & 0.01 \\
\hline 11. Being active helps me improve concentration. & 42.4 & 21.5 & 53.7 & 16.1 & 60.1 & 15.7 & $29.78^{* *}$ & $<0.01$ & 0.01 \\
\hline 12. Being active is important. & 82.8 & 4.1 & 88.3 & 2.3 & 88.0 & 3.2 & $16.37 * *$ & $<0.01$ & 0.01 \\
\hline 13. It is important to develop the habit of exercising PA. & 80.4 & 5.8 & 85.2 & 10.7 & 85.9 & 3.5 & $11.48^{* *}$ & $<0.01$ & \\
\hline 14. Being active is something I would never give up in my life. & 71.3 & 12.9 & 69.3 & 10.2 & 70.4 & 9.4 & 0.02 & 0.99 & \\
\hline 15. Although I have a lot of work to do, I try to be active. & 53.4 & 21.7 & 63.8 & 15.7 & 72.6 & 8.5 & $30.55^{* *}$ & $<0.01$ & 0.01 \\
\hline
\end{tabular}

${ }^{*} \mathrm{p}<0.05 ;{ }^{* *} \mathrm{p}<0.01$ 


\section{Discussion}

The main aim of the study in three European countries (Croatia, the Czech Republic, and Slovakia) was to compare students' opinions (aged 15-19 years) about their perceived health status in context with PA. Their opinions were obtained using a distributed questionnaire in selected high schools. Although studies using self-assessment always have their pitfalls, on the other hand, according to the Idler and Benyamini ${ }^{18}$ study, "self-ratings of health were better predictors of seven-year survival than people's medical records or self-reports of medical conditions (p. 21)". Even though perceived health status can differ among people, on the other hand, it could be the key to understand other psychosocial influences on health. The results of our self-report questionnaires indicate statistically significant differences between states in 11 of the 15 questions overall.

Quite surprising seem to be the results in which Croatian boys perceived their health as excellent or very good (29.5\%; $38.3 \%$ respectively) and there exists significant difference between Croatian students and students from other two countries. In general, we did not find any statistical data for this statement in the context of PA. Croatian children do not show better results than students from Slovakia or the Czech Republic. Although there are differences between girls and boys, their PA activity is very low. Based on the study Health behaviour in school-aged children (HBSC, 2015) only $27.4 \%$ of Croatian boys and $14.6 \%$ of Croatian girls meet the recommended WHO physical activity levels. In the Czech Republic, according to HBSC (2015) $26 \%$ of boys and $19 \%$ of girls meet it, similar to neighbouring Slovakia ${ }^{19}$. Thus, no significant differences can be discussed. In any case, these results are not flattering. It is positive that they feel healthy, but their exercise habits should improve, otherwise the WHO prediction that by $2030^{20}$ half of the population will be obese will most likely come true. Similarly to the previous example, Croatian students are more aware that PA helps them to better assess situations, unlike Czechs (better assess situation; $56.1 \%$ vs. $36.4 \%$ ). Also, the positive impact of physical activity on solving school tasks is better assessed by Croatians than Czechs (50.3\% vs. 28.8\%). We could not find out why this is the case. Again, we would rather expect the opposite result, as both in Slovakia ${ }^{21}$ and in the Czech Republic two hours of PE are compulsory, but in Croatia it depends on the institution and usually one to two hours of PE are compulsory, i.e. often less than in Slovakia and the Czech Republic. However, it is important to mention here that even the better results of Croatian students are quite low. Furthermore, in the self-report questionnaire students are fully aware of the positive relationship between $\mathrm{PA}$ and being healthy (Q8), the importance of being active (Q12) and the importance of creating a habit of physical activity (Q13). In all these questions students answered positively in more than $80 \%$ of cases. On the flip side of the results, there is low student awareness of the positive impacts of PA on better schoolwork (CZE 28.8\%, SVK 41\%, CRO 50.3\%) and the positive impacts of PA on concentration (CZE 42.4\%, SVK 53.7\%, CRO 60.1\%).
The average response rate for all questions combined for all countries is $62.06 \%$. This number may seem relatively high, but it should be remembered that the questions were designed so that ideally students would answer positively one hundred percent of the time. Consequently, work needs to be done to increase this number, which simply speaks to how well-educated students are on the positive impact of $\mathrm{PA}$ on their lives. Therefore, it is important to both educate students and incorporate progressive approaches into the PA itself so that the physical intensity is increased during the lesson itself ${ }^{22}$.

One of the main goals of PA in schools should be to promote an active lifestyle and create a habit of regular exercise. Unfortunately, this is not being achieved as most students in the Western world do not achieve the recommended regular physical activity to have a sufficient positive impact on their health ${ }^{23,24}$. In the prevention and development of physical activity, there is a need to focus mainly on the less active, less athletically gifted and those from lower economic backgrounds, as they are the ones who show less activity in adulthood ${ }^{25}$. Martins et al. ${ }^{26}$ recommend the following strategy in preventing and increasing the effectiveness of PA in schools: 1 . good education of the teachers themselves, 2. increase active time in Physical Education so that students spend at least $50 \%$ of their time in moderate or vigorous PA (most Physical Education do not achieve this ${ }^{27}$ ) - this is achieved by explaining theory more effectively and reducing less physically demanding games, 3. change the curriculum to support the previous point, 4 . increase the sense of achievement for the less gifted (not praising the outcome but the progress), 5. create a positive attachment to exercise so that pupils want to play sport outside of school hours.

In our research we also focused on gender differences. In most cases, this confirms much previous research on this topic, namely the generally more positive attitude towards $\mathrm{PA}$ in boys than in girls. This is consistent with the study by Bauman et al. ${ }^{28}$, which also included the Czech population. Greater sports activity in boys than girls is also reported in a 2017 meta-analysis ${ }^{26}$, making gender one of the most consistent correlations in $\mathrm{PA}^{28-30}$. The only significant factor in which girls found greater positive effects of PA was question nine, in which girls were more likely to report a positive relationship between better sleep and PA. This difference may be due to girls' more frequent sleep problems, as they are more likely than boys to use a smartphone before bed, since they are more active on social media and it is this activity that disrupts sleep ${ }^{31,32}$. PA, in contrast, promotes better sleep, which may be why girls are more aware of its positive influence. In any case, insufficient sleep is a recent major problem, especially in school-aged people, since $75.3 \%$ of adolescents were classified as short sleepers (sleeping an hour or less than the recommended norm) ${ }^{33}$, which only illustrates the importance of sufficient PA in adolescents $^{34}$.

There is a need to change the systemic approach to PA in the school system, which does not yet sufficiently develop good exercise habits in pupils and does not sufficiently pro- 
mote the different types of PA that an individual is able to perform at any time in their free time. The importance of $\mathrm{PA}$, especially at a young age, is a major societal issue ${ }^{35}$, considering that many chronic diseases such as obesity and type II diabetes begin during youth and it is only natural that underactive youth become underactive adults ${ }^{36}$. Diseases associated with physical inactivity shorten life by 10 to 20 years and the most common cause is cardiovascular problems ${ }^{37}$. In addition to the above-mentioned diseases, another downside of modern society should be mentioned which is the increasing psychological problems in youth ${ }^{38}$. It is physical activity that improves well-being and thus reduces psychological problems in more physically active individuals ${ }^{39}$. For the development of a healthy society, good exercise habits will be a necessity in modern times.

\section{Conclusion}

Croatian students perceive their health to be at a better level than Czech or Slovak children, although their physical activity is at the same level. Comparing gender differences

\section{R E F E R E N C E S}

1. RAVENS-SIEBERER U, TORSHEIM T, HETLAND J, VOLLEBERGH W, CAVALLO F, JERICEK H, ALIKASIFOGLU M, VÄLIMAA R, OTTOVA V, ERHART M, Int J Public Health, 2 (2009) 151. doi: 10.1007/s00038-009-5406-8. — 2. ESPAÑA-ROMERO V, WIJNDAELE K, TUXWORTH W, FENTEM PH, WAREHAM N, BRAGE S, Rev Andal Med Deport, 1 (2015) 28. doi: 10.1016/j.ramd.2014.10.023. - 3. MANDERBACKA K, LUNDBERG O, MARTIKAINEN P, Soc Sci Med, 12 (1999) 1713. doi: 10.1016/S0277-9536(99)00068-4. - 4. SHADBOLT B, Am J Public Health, 6 (1997) 951. — 5. ABU-OMAR K, RÜTTEN A, ROBINE J-M, Soz Praventivmed, 4 (2004) 235. doi: 10.1007/s00038-0043107-x. - 6. MAGEE CA, CAPUTI P, IVERSON DC, Sleep Med, 4 (2011) 346. doi: 10.1016/j.sleep.2010.09.013. - 7. VON DEM KNESEBECK O, GEYER S, BMC Public Health, 1 (2007) 272. doi: 10.1186/1471-2458-7272. - 8. HRUBY A, LIEBERMAN HR, SMITH TJ, Prev Med, 131 (2020) 105930. doi: 10.1016/j.ypmed.2019.105930. - 9. CHOI NG, J Gerontol Soc Work, 1 (2002) 65. doi: 10.1300/J083v37n01_05. — 10. NKANSAH-AMANKRA S, WALKER AD, Health Edu J, 1 (2012) 39. doi: 10.1177/0017896910386141. — 11. SCIENTIFIC ADVISORY COMMITTEE OF THE MEDICAL OUTCOMES TRUST, Qual Life Res, 3 (2002) 193. - 12. TERWEE CB, BOT SDM, DE BOER MR, VAN DER WINDT DAWM, KNOL DL, DEKKER J, BOUTER LM, DE VET HCW, J Clin Epidemiol, 1 (2007) 34. doi: 10.1016/j.jclinepi.2006.03.012. — 13. HOYT LT, CHASE-LANSDALE PL, MCDADE TW, ADAM EK, J Adolesc Health, 1 (2012) 66. doi: 10.1016/j.jadohealth.2011.05.002. - 14. STEPTOE A, O'DONNELL K, MARMOT M, WARDLE J, J Psychosom Res, 4 (2008) 409. doi: 10.1016/j.jpsychores.2007.11.008. - 15 ABUOMAR K, RÜTTEN A, Prev Med, 3 (2008) 319. doi: 10.1016/j. ypmed.2008.03.012. - 16. MOK M, CHIN MK, CHEN S, EMELJANOVAS A, MIEZIENE B, BRONIKOWSKI M, LAUDANSKA-KRZEMINSKA I, MILANOVIC I, PASIC M, BALASEKARAN G, J Appl Meas, 4 (2015) 379. - 17. MORSE DT, Educ Psychol Meas, 3 (1999) 518. doi: 10.1177/00131649921969901. - 18. IDLER EL, BENYAMINI Y, J Health Soc Behav, 1 (1997) 21. doi: 10.2307/2955359. - 19. BOBAKOVA D, HAMRIK Z, BADURA P, SIGMUNDOVA D, NALECZ H, KALMAN M, Int J Public Health, 1 (2015) 59. - 20. DOBBS R, SAWERS C, THOMPSON F, MANYIKA J, WOETZEL JR, CHILD P, MCKENNA S, SPATHAROU A, Overcoming obesity: An initial economic analysis (McKinsey Global Institute, 2014). — 21. BEBČÁKOVÁ V, MIKUŠ M, only confirms previous research findings that boys show more sports activity and a more positive attitude towards PA than girls. Girls, on the other hand, perceive a more positive effect of PA on sleep duration and quality. In view of the findings, there is a need to continuously call for a change in the attitude towards PA, especially in the field of education, where education and promotion of PA may bring positive responses in the future, either in a happier population or in reduced healthcare costs.

\section{Acknowledgements}

This work was supported by a research grant of International Council of Sport Science and Physical Education "Health, healthy lifestyle and inclusion as physical education quality component" funded between 2017-2019 and a grant from VEGA agency "Physical and sport education and its quality and potential for health promotion from pupils, parents and teachers' perspective" (No. 1/0523/19).

ŠIMONEK J, ŠVP: Telesná a športová výchova ( pedagogický ústav, Bratislava, 2009). - 22. SCHÜZ B, LI AS-W, HARDINGE A, MCEACHAN RR, CONNER M, Psychol Sport Exerc, 30 (2017) 186. doi 10.1016/j.psychsport.2017.03.004. - 23. SALLIS JF, BULL F, GUTHOLD R, HEATH GW, INOUE S, KELLY P, OYEYEMI AL, PEREZ LG, RICH ARDS J, HALLAL PC, Lancet, 10051 (2016) 1325. doi: 10.1016/S0140. 6736(16)30581-5. - 24. HALLAL PC, ANDERSEN LB, BULL FC, GUTHOLD R, HASKELL W, EKELUND U, LANCET PHYSICAL ACTIVITY SERIES WORKING GROUP, Lancet, 9838 (2012) 247. doi: 10.1016/S0140-6736(12)60646-1. - 25. STALSBERG R, PEDERSEN AV, ScandJ Med Sci Sports, 3(2010) 368. doi: 10.1111/j.1600-0838.2009.01047.x. - 26. MARTINS J, MARQUES A, PERALTA M, PALMEIRA A, DA COSTA FC, Retos, 31 (2017) 292. - 27. MCKENZIE TL, LOUNSBERY MA, Res Q Exerc Sport, 4 (2013) 419. doi: 10.1080/02701367.2013.844025. - 28. BAUMAN AE, BULL FC, CHEY T, CRAIG CL, AINSWORTH BE, SALLIS JF, BOWLES HR, HAGSTROMER M, SJOSTROM M, PRATT M, THE IPS GROUP, Int J Behav Nutr Phys Act, 1 (2009) 21. doi: 10.1186/1479-5868-6-21. — 29. BIDDLE SJ, ATKIN AJ, CAVILL N, FOSTER C, Int Rev Sport Exerc Psychol, 1 (2011) 25. doi: 10.1080/1750984X.2010.548528. - 30. STERDT E, LIERSCH S, WALTER U, Health Edu J, 1 (2014) 72. doi: 10.1177/0017896912469578. — 31. CONKLIN A, YAO C, RICHARDSON C, Eur J Public Health, Supp. 4 (2019) ckz185.024. doi: 10.1093/eurpub/ckz185.024. — 32. LUNDH L-G, BJÄREHED J, WÅNGBY-LUNDH M, J Psychopathol Behav Assess, 1 (2013) 85. doi: 10.1007/s10862-012-9307-4. — 33. GÁBA A, DYGRÝN J, ŠTEFELOVÁ N, RUBÍN L, HRON K, JAKUBEC L, PEDIŠIĆ Ž, Int J Behav Nutr Phys Act, 1 (2020) 104. doi: 10.1186/s12966-020-01004-8. - 34. BADICU G, Sustainability, 7 (2018) 2410. doi: 10.3390/su10072410. - 35. WHO, Report of the first meeting of the ad hoc working group on science and evidence for ending childhood obesity: 18-20 June 2014, (WHO, Geneve, 2014). - 36. TELAMA R, YANG X, LESKINEN E, KANKAANPAA A, HIRVENSALO M, TAMMELIN T, VIIKARI JSA, RAITAKARI OT, Med Sci Sports Exerc, 5 (2014) 955. doi:10.1249/ MSS.0000000000000181. - 37. LAURSEN TM, MUNK-OLSEN T, VESTERGAARD M, Curr Opin Psychiatry, 2 (2012) 83. doi:10.1097/ YCO.0b013e32835035ca. - 38. BIDDLE SJ, ASARE M, Br J Sports Med, 11 (2011) 886. doi:10.1136/bjsports-2011-090185. — 39. FOX KR, Public Health Nutr, 3 (1999) 411. doi:10.1017/S1368980099000567. 


\section{J. Malis}

Palacky University Olomouc, Faculty of Physical Culture, tř́lda Míru 117, 77111 Olomouc, Czech Republic

e-mail:ibn@seznam.cz

\section{PERCEPCIJA ZDRAVSTVENOG STANJA I VAŽNOSTI TJELESNE AKTIVNOSTI MEĐU HRVATSKOM, SLOVAČKOM I ČEŠKOM MLADEŽI}

\section{S A Ž E T A K}

Glavni cilj istraživanja bio je usporediti samopercepciju zdravstvenog stanja i važnost tjelesne aktivnosti kod studenata u Hrvatskoj, Slovačkoj i Čškoj. Korišten je upitnik koji je orginalno izdrađen na slovačkom jeziku, a koji je kasnije preveden na maternji jezik za češke i hrvatske studente. Upitnik se sastoji od pet dijelova (ovo istraživanje usredotočeno je samo na jedan dio - tjelesna aktivnost i zdravlje) i osnovnih demografskih podataka. Upitnik je ispunilo 1368 učenika prvog i posljednjeg razreda srednjih škola. Za odgovore na 15 tvrdnji učenici su koristili Likertovu skalu od 5 stupnjeva. Velik broj hrvatskih učenika svoje je zdravstveno stanje ocijenjeno odličnim ili vrlo dobrim u odnosu na češke i slovačke učenike. Učenici smatraju da im tjelesna aktivnost pomaže da održe svoju fizičku formu i bolje procijene situacije u svakodnevnom životu. Važnost tjelesne aktivnosti važno je stalno promovirati jer ne samo da čini ljude spremnima, već im pomaže da bolje rade, uče i opuštaju se. 